\title{
A Transnational Approach to Wartime Press Photography: The Case of Randall Chase Gould (1898-1979) and His Coverage of the Battle of Shanghai (August-November 1937) $^{1}$
}

\begin{abstract}
This article focuses on the role of photography in the context of the Battle of Shanghai (August-November 1937), one of the first major conflicts of the Second Sino-Japanese War (1937-1945). An examination of the written and photographic work by American journalist Randall Chase Gould (1898-1979), editor of the American-owned, English-language Shanghai Evening Post and Mercury (SEPM), addresses the question of how he covered the Battle of Shanghai for various transnational audiences. In pursuing an interdisciplinary approach based on transnational journalism history combined with the theoretical framework of the photographic message according to Roland Barthes, this study traces how Gould's photographs were 'read' by multiple audiences in different transnational contexts. An examination of two of Gould's photographs will highlight the dynamic interrelation between texts and images and will show how images constituted a crucial part of the intended message(s) in media reports on the Battle of Shanghai addressed to transnational audiences.
\end{abstract}

\section{Keywords}

transnational journalism history, press photography, Second Sino-Japanese War, Shanghai, text-image analysis

\section{Introduction}

When the Japanese Imperial Army attacked Shanghai on 13 August 1937, the political tensions between the Republic of China and the Empire of Japan erupted in an armed conflict which brought death and destruction to the cosmopolitan metropolis. The so-called Battle of Shanghai (淞滬會戰 Songhu Huizhan) 
raged in the city for three months until 26 November 1937, and constituted one of the first major conflicts of the Second Sino-Japanese War ${ }^{2}$ (1937-1945). As Shanghai and its residents witnessed disaster and destruction of unprecedented scale, the city became the centre of attention for audiences both within and outside of China. There were two main reasons why the events in Shanghai were followed closely by people around the world. First, a major metropolis (then the world's fifth largest city) was experiencing mass killings resulting from modern warfare, shocking both the city's inhabitants and the world. ${ }^{3}$ Second, Shanghai was not only a port of global importance but also a city shaped by what Isabella Jackson has described as 'transnational colonialism', whereby within the Shanghai International Settlement 'colonial authority [was] in the hands of not one nation and its officials but many non-state actors from diverse backgrounds' ${ }^{4}$ The International Settlement and the French Concession were designated foreign settlements in Shanghai whose establishment was rooted in the British victory in the First Opium War (1839-1842) and the subsequent signing of the Treaty of Nanjing (1842). The terms of the treaty opened Shanghai, along with other Chinese port cities, to foreign trade and settlement, and also paved the way for the formation of areas where foreign nationals could benefit from extraterritorial rights and consular jurisdiction. While the French Concession remained a separate entity exclusively under French authority, the International Settlement was initially formed when the British and American settlements merged in $1863 .{ }^{5}$ As more foreign powers entered into treaties and established trade relations with China, the International Settlement became increasingly diverse. This circumstance was reflected in the seal of the Shanghai Municipal Council, the institution which governed the International Settlement. In use since 1869, the seal featured the flags of twelve Western nations with interests in Shanghai: the United Kingdom, the United States, France, Spain, Italy, Portugal, the Netherlands, Denmark, Norway-Sweden, Austria-Hungary, Russia, and Prussia, whose flag was covered by a white space after the First World War (1914-1918). ${ }^{6}$

The city's international setting further ensured foreign attention, especially in the event of war. As all eyes turned towards Shanghai, large and diverse audiences demanded continuous news on the conflict's developments. To meet this demand, journalists rushed to gather the latest news for local, international, and multilingual newspapers and news services, providing them with written news, photographs, and newsreels. Shanghai's wartime experiences thus resulted in an increased transnational circulation of news and images centred on the Battle of Shanghai. 
For the purposes of this study, transnational media flows and consumption are key concepts. The transnational dimensions of news coverage on the war erupting in China were reflected in several factors. According to Marie Cronqvist and Christoph Hilgert, "'transnational” implies the existence of phenomena which are located in a heterogenous spatio-temporal framework (...) that transgresses or operates irrespective of formal nation-state boundaries. ${ }^{7}$ In the case of Shanghai, the geographical dispersion of the target audiences located outside of China and the national diversity of the targeted readership in Shanghai underline the need to analyse news items created in and for this context in a framework beyond the paradigm of any single nation-state. This article argues that the proposed approach is especially significant regarding the case of press photographs centred on the Battle of Shanghai, due to photography's ability to address audiences beyond linguistic or national constraints. In addition, transnational public interest in the war in Shanghai pushed press services located abroad to increase their use of new, faster, and more expensive communication technologies. Technological services such as wirephoto and the 'urgent' telegraph service were employed to send reports and images across the world, resulting in the highest transmission costs since WWI. ${ }^{8}$ With twentieth-century technological advancements further closing the gaps between the localities of news and their audiences, approaches to the reception of textual and visual transnational media become even more significant.

This article will examine the role of photography in the context of reporting the Battle of Shanghai in two distinct transnational spheres: both outside and within the inherently transnational city. In doing so, this contribution aims to offer a deeper understanding of the mechanisms of transnational news reporting in wartime journalism in Shanghai. The written and photographic work by American journalist and editor Randall Chase Gould (1898-1979), who operated at the heart of the city's English-language press landscape, will serve as a case study. In his function as the editor of the American-owned, English-language Shanghai Evening Post and Mercury (SEPM), Gould was one of the city's most influential foreign correspondents during the Battle of Shanghai. This study is based on archival material from the Randall Chase Gould papers held at the Hoover Institution Archives, Stanford University, CA, as well as additional resources from the French Diplomatic Archives in Nantes (Centre des Archives diplomatiques de Nantes). From Gould's papers, two photographs from image-based primary sources illustrating the Battle of Shanghai will be examined in detail. The photographs, which I have titled 'Garden Bridge' and 'Bloody Saturday', were both taken on 14 August 1937. The images are located in Gould's photo album titled Shanghai Shambles: Sino-Japanese Conflict 
$1937^{9}$, and in a pictorial section published by the SEPM titled Pictorial Review of Shanghai Hostilities, Aug. 9 - Nov. $12^{10}$, dated 4 December 1937. Both of these sources have been largely neglected in academic research until now.

An examination of this material will address the question of how Gould covered the Battle of Shanghai using texts and photographs for audiences in the city and beyond. To explore this question, this article will first focus on why a transnational approach to press photography is necessary. It will then address the contexts of the SEPM's establishment along with its circulation and readership. After providing the historical background for the Battle of Shanghai, Randall Chase Gould's approach to press photography will be discussed in order to examine his 'Garden Bridge' and 'Bloody Saturday' photographs in detail.

Serving as the methodological lens will be Roland Barthes' concept of the photographic message as an entity formed equally by two communicating structures: the linguistic structure (captions, labels, titles), and the visual structure (the photograph itself). ${ }^{11}$ First, Gould's 'Garden Bridge' photograph and its corresponding texts will be subjected to a close reading in three separate transnational publication contexts. In highlighting the interplay between the linguistic and visual structures, the analysis will reveal how the image was geared towards different audiences as it encouraged alternative 'readings' in the respective contexts. The analysis will show how the photograph constituted a crucial part of the intended message(s) in media reports on the conflict addressed to a transnational readership, but also how its meaning was inextricably entwined with the accompanying captions and texts.

As a second step, Gould's ‘Bloody Saturday’ photograph will be examined in two contexts: its album format as seen in Gould's photo album Shanghai Shambles, and its published version released by the SEPM, which appeared in the Pictorial Review on 4 December 1937. By comparing the two versions, this article will then show how the image was prepared and altered for publication by the SEPM in order to address the transnational and multilingual audience within Shanghai. This approach is crucial since news reports and images published in Shanghai newspapers such as the SEPM were often designed to be consumed by a diverse audience (as will be discussed below). Therefore, certain members of this audience did not necessarily primarily connect with the captions due to language barriers, but often carefully studied the images instead. Specifically, the effects of image editing on the visual structure of the 'Bloody Saturday' photograph and on its interaction with the respective captions will be examined closely. In tracing how the photographic message was changed, this study 
will highlight the impact of visual editing and other aspects such as selection and framing on the reception of the photograph by Shanghai's transnational audience.

In placing a specific focus on the role of photography in a context of transnational news circulation, this article will critically investigate the diverse information provided by the visual and textual sources produced by Gould and the SEPM during the Battle of Shanghai. By examining the photographs and their accompanying texts through the lens of the Barthesian concept of the photographic message, this article will therefore discuss photographs as central primary sources rather than secondary illustrative placeholders.

\section{A transnational approach to press photography in Shanghai}

According to Marcel Broersma, transnational journalism history as a field of study is centred on 'cross-national interaction, the movement of agents, ideas, innovations, norms and social and cultural practices across borders, and their consecutive incorporation and adaption into national frameworks'. ${ }^{12}$ Thus, transnational journalism history both acknowledges and underlines the consequences of an increasingly interconnected world and its effects on journalistic practices. Since illustrations and photographs represented essential parts of media reports in the context of wartime Shanghai, it is crucial to outline why a transnational approach to them is not only justified, but necessary.

First, photography's potential to address audiences across linguistic and political borders suggests an inherently transnational baseline. According to Susan Sontag, while written accounts have the tendency to either include or exclude audiences based on 'complexity of thought, reference, and vocabulary (...) a photograph has only one language and is destined potentially for all'. ${ }^{13}$ Second, language plays an essential part in conjunction with press photography. As Roland Barthes has shown, any form of text accompanying an image is an integral part of its message and must be analysed as such. ${ }^{14}$ In Shanghai, language diversity was one of the core aspects of newspaper publishing. In the 1930s, Shanghai's press landscape included publications in Chinese, English, French, Japanese, Russian, and German. ${ }^{15}$ In the pursuit of new readers, publishers addressed the issue of language in various ways, perhaps most evidently in the establishment of bilingual pictorial supplements. The SEPM also adopted this strategy, which reflected the transnational setting of press photography in Shanghai. 
The third point to highlight the necessity for a transnational approach lies in the circulation of the SEPM. The SEPM reached a diverse readership which was not limited to the anglophone foreign residents of Shanghai, but also included the city's Chinese elites as well as foreign subscribers outside China. ${ }^{16}$ According to Yong Z. Volz and Chin-Chuan Lee, around 2,000 copies of the SEPM were destined for overseas subscribers daily in the 1930s, a practice shared by a distinct majority of foreign news publications in China, some of which even had their own distribution centres abroad. ${ }^{17}$ The SEPM had a steady circulation beyond China which included other parts of East Asia. This diversified distribution was not limited to the main edition of the SEPM alone but also included its pictorial supplements. For example, the English-Chinese bilingual supplement China in Pictures: The Shanghai Evening Post and Mercury's Graphic March of Time in China was first published on 15 May 1938, and had a daily circulation of 3,500 copies across Shanghai, Hong Kong, Guangzhou, Manila, and the Straits Settlements. ${ }^{18}$ Therefore, it is significant to emphasise that photographs published by the SEPM were created to be consumed by transnational audiences encompassing a broad spectrum of readers ranging from colonial subjects to citizens of East Asian and Western states.

Fourth, Randall Chase Gould himself worked in a twofold transnational sphere. He not only addressed an audience in and beyond Shanghai in his function as the editor of the SEPM but also worked as a correspondent for the renowned Christian Science Monitor, writing for an even broader international public - an experience Gould described as 'one of the most pleasant work companionships of [his] life'. ${ }^{19}$ Gould's name was therefore widely recognised among the diverse readerships of both the SEPM and the Christian Science Monitor.

\section{The birth of a transnational newspaper: The Shanghai Evening Post and Mercury}

Over the course of ten years, from 1931 to 1941, Randall Chase Gould held the editorship of the SEPM in Shanghai. By the time Gould became editor, the newspaper had just undergone structural changes which affected the publication's political orientation and its way of reporting.

The SEPM was the result of a merger of two newspapers, the Shanghai Evening Post and the Shanghai Mercury. ${ }^{20}$ Prior to the merger, the American-registered Shanghai Evening Post had been owned by American businessman Cornelius Vander (C. V.) Starr (1892-1968) and was edited by fellow American journalist and adman Carl Crow (1883-1945). In August 1930, the Shanghai Evening Post bought the British-owned Shanghai Mercury, then edited by British journalist Henry George 
Wandesforde (H. G. W.) Woodhead (1883-1959), and the resulting amalgamation was named the Shanghai Evening Post and Mercury. ${ }^{21}$ Following the merger, the American-registered SEPM was the only English-language daily evening newspaper in Shanghai. Its circulation increased steadily after its establishment. When Gould first joined the newspaper, the daily circulation of the SEPM stood at around 5,000 copies, increasing to 7,250 copies in 1937, the year that saw the Battle of Shanghai. ${ }^{22}$ By January 1940, these numbers had risen again, with the French authorities estimating the newspaper's daily circulation at between 11,000 and 12,000 copies. ${ }^{23}$

The political position of the SEPM was not as clear-cut as its administrative structure as an American-owned and -registered newspaper in Shanghai would suggest. The diverging political views held by Randall Chase Gould and H. G. W. Woodhead, two of the newspaper's main contributors, played an important role. Woodhead wrote a daily column for the SEPM titled "As a Briton Sees It". C. V. Starr, the owner of the paper, had given the column to Woodhead in the hope that his prominent name would attract more British readers. ${ }^{24}$ However, Gould described Woodhead's work as 'our oddest column', ${ }^{25}$ since his writings often expressed pro-British and sometimes pro-Japanese tendencies, which went directly against Gould's political stance and editorial policies. The resulting confusion regarding the newspaper's political direction was shared by the French authorities. In a contemporary study of the press in Shanghai, they underlined the ambivalence between the SEPM's impartiality regarding Chinese nationalist endeavours and Woodhead's repeated defence of foreign rights in China:

Although the ‘Shanghai Evening Post \& Mercury’ professes great impartiality with regard to Chinese nationalist aspirations, the presence of Mr W. Woodhead, one of the most notorious British 'die-hards', within his editorial staff makes the newspaper one of the most active defenders of the rights of foreigners in China. ${ }^{26}$

Contrary to Woodhead's opinions, Randall Chase Gould advanced a different view when he joined the SEPM in 1931, in particular following the Manchurian Incident of 18 September of that year; Gould recalled in his unpublished memoirs that 'despite murmurings that "the Japanese are only holding the line for all foreigners" I proceeded to whack out sharp criticism of Japanese policy and action'.27 Gould's position can be explained to a large extent by the heterogeneous composition of the SEPM's audience. When Gould first joined the newspaper, a contemporary analysis of its distribution identified about half the readership as Chinese. ${ }^{28}$ Starting in 1933, the SEPM also began to publish a Chinese edition, the Da Mei Wan Bao 大美晚報, which was 'supposed to be a vernacular version of the 
Post, with [Gould] as editor in spite of [his] relative ignorance of written Chinese'. ${ }^{29}$ The Chinese edition contributed to an even broader circulation and increased readership numbers, reaching 40,000 copies daily by $1941 .{ }^{30}$ Finally, the SEPM's range was not limited to Shanghai alone: according to Peter O'Connor, the publication accounted for 23\% of all English-language newspaper sales in Shanghai, as well as $10 \%$ of the total sales in China in the late 1930 s. $^{31}$

The SEPM had a diverse readership and far-reaching circulation, and Gould, as its editor, had global connections from his simultaneous engagement as a correspondent for the Christian Science Monitor and his previous work experience as bureau manager of the United Press in Beijing and Manila. ${ }^{32}$ Gould thus had a very influential voice, which was essential in reporting on some of East Asia's most crucial events of the twentieth century, including the Battle of Shanghai.

\section{War in the midst of the metropolis: The Battle of Shanghai (August-November 1937)}

In Shanghai, August was to be our fatal month and we awaited developments with something of the supposed hypnosis of bird before snake. We had no way to turn, no place to go. That we had no stomach for involvement was entirely beside the point. ${ }^{33}$

In his memoirs, Randall Chase Gould recorded his account of the Japanese attack on Shanghai. From his viewpoint as an American citizen protected by extraterritorial privileges, August 1937 was a time characterised by collective, paralysing fear shared by fellow residents of the International Settlement. In order to understand the focus of Gould's reporting at this point in time, it is important to contextualise the Battle of Shanghai within the larger historical framework surrounding the Second Sino-Japanese War.

The eruption of violence in Shanghai did not start spontaneously but constituted an escalation of decades of rising tensions between China and Japan. ${ }^{34}$ The initial stage of the conflict, known today as the Battle of Shanghai, lasted for three months, until November 1937. It was not the first time for Shanghai to become a theatre of war, as the city had witnessed a Japanese attack just five years earlier. However, while the 1932 advance represented the first instance of modern warfare inflicted on Shanghai, it was shorter in duration and had been fought on a lesser scale compared to the 1937 conflict, which quickly engulfed the city and resulted in total chaos and destruction, turning nearly a million people into refugees. ${ }^{35}$ 
As a further consequence of the 1937 battle, all parts of Shanghai except the International Settlement and the French Concession fell under Japanese occupation. ${ }^{36}$ However, while their extraterritorial status initially protected the International Settlement and the French Concession from immediate occupation and made them relatively safe places, it did not mean that these areas escaped the violence of war entirely. There were two incidents where Chinese planes accidentally bombed the foreign settlements, killing thousands of civilians. ${ }^{37}$

As the Battle of Shanghai continued and the number of civilian victims grew, the local and global demand for both written and photographic coverage increased accordingly. This demand was met by journalists from a multitude of backgrounds working for multilingual news outlets. Among them was Randall Chase Gould, who not only witnessed the Battle of Shanghai at first hand, but also covered the events for the SEPM in both written and photographic form.

\section{Shanghai Shambles: Sino-Japanese Conflict 1937: Randall Chase Gould's approach to press photography}

Gould was an avid and prolific photographer during the 1937 Sino-Japanese conflict in Shanghai. His role as a photographer has been largely overlooked until now, although historical research literature occasionally refers to his photographs as historical source material. ${ }^{38}$ Gould never referred to himself as a photojournalist in the professional sense, which on the one hand was probably due to the fact that he clearly identified himself as the editor of the SEPM, and on the other hand because photojournalism as a distinct profession was still developing in the 1930s. However, his affinity to photography is apparent in multiple contexts. For example, he actively participated in photography contests: in 1937, the Sunday supplement of the North-China Daily News held several photography competitions, and in the issue titled The Hostilities In and Around Shanghai from 1 December, a photograph by Randall Chase Gould was presented as one of the winning images. ${ }^{39}$ In addition, Gould maintained a close personal friendship with American businessman Mark L. Moody (1892-1955), who was not only his car dealer but also an enthusiastic fellow photographer and film director. ${ }^{40}$ Moody became known as the director of the 1942 film Ravaged Earth, which focused on the Battle of Shanghai and was described at the time as 'one of the most revealing documents of the bestiality of war in camera history'. ${ }^{41}$

In the context of the battle, Gould produced and collected a number of photographs which are preserved in six photographic albums as part of the Randall Chase Gould paper collection at the 
Hoover Institution Archives. ${ }^{42}$ The album titled Shanghai Shambles: Sino-Japanese Conflict 1937 (album $\mathrm{fH}$ ) is especially significant in this context as it contains the photographs centred on the Battle of Shanghai. ${ }^{43}$ This album is a unique source for numerous reasons. First, not only is it possible to identify Gould as the creator of the images, but the album also displays the photographs in the manner intended by the photographer, including their selection, positioning and sequence. Second, to accompany the album, Gould wrote a document titled Key to Photo Album Shanghai Shambles, which is dated to 1970 and contains captions for selected photographs. ${ }^{44}$ These captions are particularly valuable, since written commentaries by photographers providing context and background information on their own images often remain elusive as an archival resource. Even though they were written long after the 1937 conflict, the captions still provide vital insights regarding the aspects of Gould's images that he chose to emphasise. Third, since some of the photographs from the album appeared in other publications, including the Pictorial Review of Shanghai Hostilities, Aug. 9 - Nov. 12, published by the SEPM on 4 December 1937, it is possible to compare the captions and to trace factors such as image editing and its effects. Therefore, an analysis of the material centred on Gould's own photographic coverage of the war in Shanghai offers the opportunity to examine the role of photography in newspaper publishing from two new perspectives. First, by introducing the photographer as an actor, it is possible to follow his agency in the creation of the selected photographs and to relate to his view on why and how they were taken and published. Second, an examination of two photographs published in various transnational publication contexts will reveal the strategies used to construct the photographic message, the approaches taken in framing and presenting the images, and how they were 'read' and perceived by different audiences.

\section{The 'Garden Bridge' photograph (14 August 1937)}

Gould arranged the photographic prints in the Shanghai Shambles album in such a way as to illustrate the conflict through a visual chronological order of events. In doing so, he chose his perhaps bestknown photograph (Figure 1), taken on 14 August 1937, to begin telling the story of how the foreign settlements in Shanghai became places of refuge. Prominently located on the first page of the album, the photograph shows an urban setting with a crowded bridge spanning a body of water, merging into a street on the other side. Taken from a bird's eye view, the focal point of the photograph is the masses of people located on the bridge and in the street. While the image does not reveal any reason 
TMG 24 (1/2) 2021

Anna Elisabeth Herren

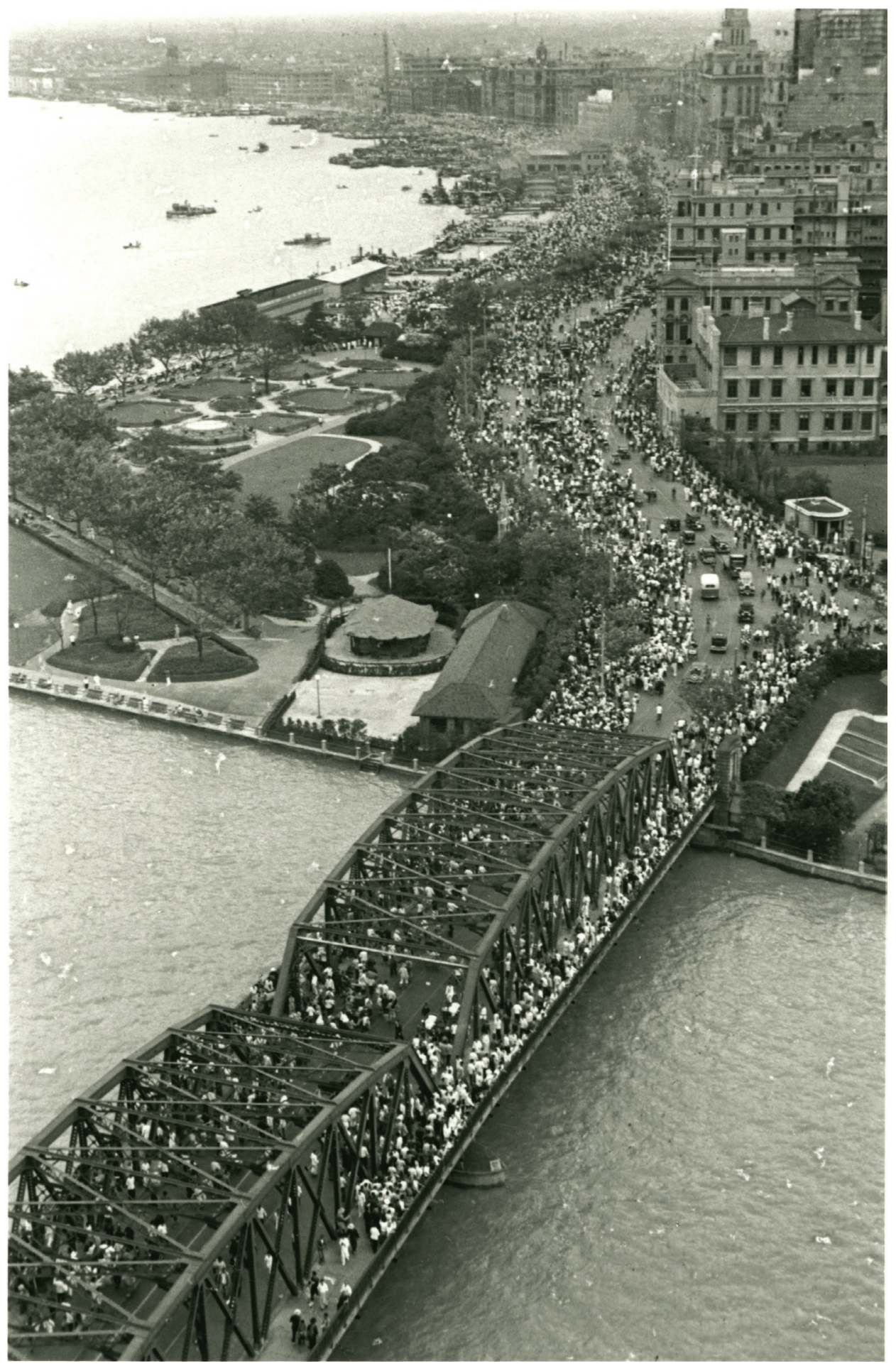

Figure 1. Garden Bridge, Shanghai, 1937, photo album Shanghai Shambles: Sino-Japanese Conflict 1937, page 1, Randall Chase Gould Papers, Box 14, Album fH, Hoover Institution Archives. 
for the presence of the crowds, its accompanying caption does. In his 1970 Key to Photo Album Shanghai Shambles, Gould wrote:

Here the story of the 1937 Sino-Japanese hostilities begins. Refugees poured across Shanghai's Garden Bridge on Aug. 14, shooting having begun in the outskirts the day previous. I snapped the left-hand photo with my Leica from the windows of my publisher's apartment (the late C. V. Starr) atop Cathay Mansions and it has appeared with my permission, but no revenue, in at least five books by others. It has also appeared in Life, which refused it in small size from me but later bought it from Black Star which had bought European rights and had no business offering it in New York. ${ }^{45}$

As well as revealing the photograph's wartime context and identifying the crowds of people as refugees, the caption delivered additional information on how and from where the image was taken. Gould's text also disclosed that the photograph appeared in multiple highly transnational contexts, three of which will be analysed below. Perhaps most prominently, it was published in Life Magazine on 13 September 1937, without crediting Gould as the photographer. ${ }^{46}$ It appeared together with two other photographs as a photo page in conjunction with an article titled "The Chinese Outfight the Japanese as Shanghai Blazes”. Its accompanying caption identified the scene as 'Refugees cross Garden Bridge to International Settlement'. In the article, the image was referenced but no additional contextual information regarding the war was given. Instead, the text pointed out a number of landmarks visible in the image, such as the Bund Garden on the left-hand side:

The pictures on these pages show the ticklish international situation created by a sovereign independent islet (Shanghai's International Settlement) in the middle of war. On the opposite page (top, right) is the Garden Bridge across Soochow Creek, connecting the Settlement with the Japanese district. (Notice that traffic goes on the left in Shanghai.) The park at left is the Bund Garden. At right is the edge of the grounds of the Shanghai Rowing Club docks; beyond the kiosk entrance to the British Consulate. ${ }^{47}$

This case illustrates how the linguistic structure could greatly influence the photographic message as a whole. Instead of responding to the photograph's focal point (the masses of people), the text guided 
the viewers' gaze towards the landmarks of the city, therefore resetting the focus of the image on the city rather than the refugees. In this context, Gould's photograph was not used to give additional details on the situation in Shanghai, but to provide a transnational audience with some knowledge of the city's geography and layout in order to explain where the conflict was taking place.

Gould's image also appeared in a Chinese-language book on the conflict published by the SEPM in 1938 in Shanghai. The publication, titled 中日戰事史蹟 Zhongri zhanshi shiji (A Historical Account of the Sino-Japanese Hostilities), was divided into two parts: a written report on the events in Chinese and a photographic account with captions in English and Chinese. ${ }^{48}$ Gould's image was placed prominently at the beginning of the photographic section as a full-page photograph. Its bilingual caption gave more detailed information on the circumstances that had caused the wave of refugees on this day:

Refugees streaming over the Garden Bridge to a haven of safety just before three Chinese bombers flew over and made an attempt to bomb the H.I.J.M. Flagship, the Idzumo. This mass of humanity became a milling mob as pandemonium broke when anti-aircraft guns came into action and the three planes tossed their missiles in a vain attempt to hit the Idzumo. ${ }^{49}$

In this context, the linguistic structure confirmed the refugees as the main point of the photographic message. It also provided additional information on the situation as well as details of an impending air attack on the bridge. In doing so, the caption not only defined the scene (as had the caption in Life Magazine), but also contextualised it in the framework of the war's course of events on that day. Therefore, the caption and the photograph reflected the aim of the book, which was to give a detailed day-to-day account of the Sino-Japanese conflict in Shanghai. As the text emphasised local developments and was predominantly written in Chinese, the publication's target audience most likely consisted of Chinese-speaking, Shanghai-based readers seeking an in-depth written and photographic chronology of these wartime events.

In December 1937, the 'Garden Bridge' image also appeared in the American magazine Leica Photography alongside an article by Gould titled "Covering the War" ${ }^{50}$ Here, the image appeared in smaller size, with its caption identifying the scene in a way similar to the cases examined above: 'Refugees streaming across the Garden Bridge toward the International Settlement'. ${ }^{1}$ The text of the article, however, focused on the equipment Gould used to take the image, and how it was received: 
I purchased my Leica shortly before the 1937 edition of Shanghai's Sino-Japanese war broke out, and the events of the 'bloody Saturday', August 14th confirmed me as a Leica bug. (...) In order to keep an eye on the situation I went to the seventeenth floor apartment of the owner of the paper. In an idle moment I pointed the Leica over the Garden Bridge toward the Bund, business center of the International Settlement, and took two or three shots of the Chinese refugees streaming away from 'north of the Creek' which had been thoroughly bombed and was soon to be closed off and exclusively Japanese-occupied as a battlefield. This picture was reproduced in several local magazines and has been much in demand because it epitomizes the spirit of the curious Shanghai war without the repulsive horrors of most of the war pictures. ${ }^{52}$

Here, Gould himself had written the text to accompany his image. Aside from explaining the context of the photograph, the article focused on Gould's own agency as a photographer and how he came to take the image. As such, the text was in line with the publication's purpose as a photography magazine. Furthermore, the text underlined why this particular image was in high demand, delivering additional information regarding the photograph's reception. However, based on the magazine's target audience of camera enthusiasts and amateur photographers, it is possible to arrive at another reading of the photographic message. By prominently identifying the make of the camera, the text subtly encouraged the readers to view the image with a focus on its quality and clarity, thus drawing their gaze away from the image's contents and towards its execution. Therefore, in conjunction with the magazine's purpose, the linguistic and visual structures created a new photographic message together: an advertisement for Leica cameras.

Across the three transnational contexts, the various captions for the same photograph identified it as a war image, even though it did not contain any self-evident traces of warfare in progress. In this way, all three audiences were made aware of its war context. According to Gould's article in Leica Photography, the absence of graphic scenes was one of the main advantages of the photograph, predisposing it for wide circulation. While the short captions used to describe the scene were worded similarly in all three cases, the differences in information given in the accompanying texts led to three further readings of the image and the construction of three diverging photographic messages. They ranged from an identification of Shanghai's landmarks as an orientation guide for non-residents to an in-depth documentation of the war's course of events to an advertisement for 
Leica cameras. These three readings of the same photograph illustrate how the linguistic structures focused on different details within the image (for example, Shanghai's landmarks), which, together with the visual structures, led to both a new reading of the image and new information for the audience. Therefore, the image formed a crucial part of the intended message(s) in news reports addressed to transnational audiences in this context, since it could be used to provide essential information which could not be conveyed solely through the text. Simultaneously, the examined cases have shown how the accompanying texts also strongly guided the viewers to a certain reading of the photograph, thus underlining the direct interdependence of the image and the linguistic structures in their creation of different photographic messages. Finally, the various photographic messages also reveal how the same event within the Battle of Shanghai was interpreted differently by separate audiences with diverging interests, priorities, and levels of contextual knowledge.

\section{The ‘Bloody Saturday’ photograph (14 August 1937)}

In order to examine how Gould's photographs were used to report on the Battle of Shanghai in yet another transnational context, this section focuses on one of his images centred on 'Bloody Saturday', published in the Pictorial Review of Shanghai Hostilities, Aug. 9 - Nov. 12, released by the SEPM in Shanghai on 4 December 1937. As shown above, the SEPM addressed a multilingual and transnational readership in Shanghai and beyond. It is therefore highly probable that the Pictorial Review, as an image-based publication with a small amount of accompanying text, was published to attract and address the highest possible number of people without requiring a in-depth understanding of English. Therefore, a comparison between the presentation of the ‘Bloody Saturday' image in its album version and in its published version allows for an examination of how the photograph was prepared and altered for publication, and thus how its visual language was sharpened to maximum effect. In discussing the image's preparation and framing, this section will analyse the construction of the photographic message in a transnational context, where for many audience members the captions were of secondary importance.

Returning to Gould's album, pages two and three present images taken from various vantage points in order to continue to illustrate the stream of refugees crossing the Garden Bridge. Page four marks the start of Gould's photographic documentation of the so-called 'Bloody Saturday'. He created these images on the same day as the 'Garden Bridge' photograph - 14 August 1937 - when, on two 
occasions, Chinese planes accidentally bombed the foreign settlements, resulting in the deaths of thousands of people, many of whom were refugees. ${ }^{53}$ In focusing on the destruction and the piles of bodies strewn across the road, Gould's photographs show the devastating scenes after the impact of the second bombing of the day, which hit the busy intersection in front of the 'Great World' amusement centre.

When comparing Gould's ‘Bloody Saturday’ photographs from the album with the photographs published in the Pictorial Review of Shanghai Hostilities, it is possible to recognise that several of the images are identical. Therefore, it is very likely that Randall Chase Gould was the photographer of some of the images published in the newspaper he edited. This context creates a unique possibility to compare the album version of a photograph with its printed version in the Pictorial Review, and thus allows for an examination of the alteration and framing techniques applied before publishing the image, along with a discussion of their effects on the image's audiences. The Pictorial Review was published to illustrate Shanghai's war-ravaged situation in the aftermath of the battle, which had just ended in late November. In the 4 December issue, the SEPM utilised the 24 pages of its pictorial section to mainly provide a visual summary of the entire three months of fighting, including the events of 'Bloody Saturday'.

One of the ‘Bloody Saturday’ photographs from Gould’s album (Figure 2), which was also printed in the Pictorial Review (Figures 3 and 4), shows bodies piled up at the side of the road in front of destroyed shops. An empty tram is located in the background, with a group of people observing the scene. In the immediate foreground on the left-hand side, a man in a white shirt stands with his back to the camera. He is observing a dramatic scene happening in front of him: a man wearing a lightcoloured jacket running towards another man lying on the ground among the victims with his left arm raised, signalling for help. When comparing Gould's photograph from the album with the printed image published in the Pictorial Review, significant differences can be noted. The newspaper version of the image, though blurred by age and print quality, shows clear signs of cropping - especially on the photograph's upper and left sides. The effect of this cropping technique is striking: by cutting off a significant part of the left side, several people standing at the edge of the pile of bodies in the photograph from Gould's album are no longer part of the image - including the man in the white shirt in the foreground and the man running to assist the presumably wounded man on the ground. The victim with the raised arm, however, was not cut out. Instead, his body is now located at the extreme left side of the cropped published version of the image. 


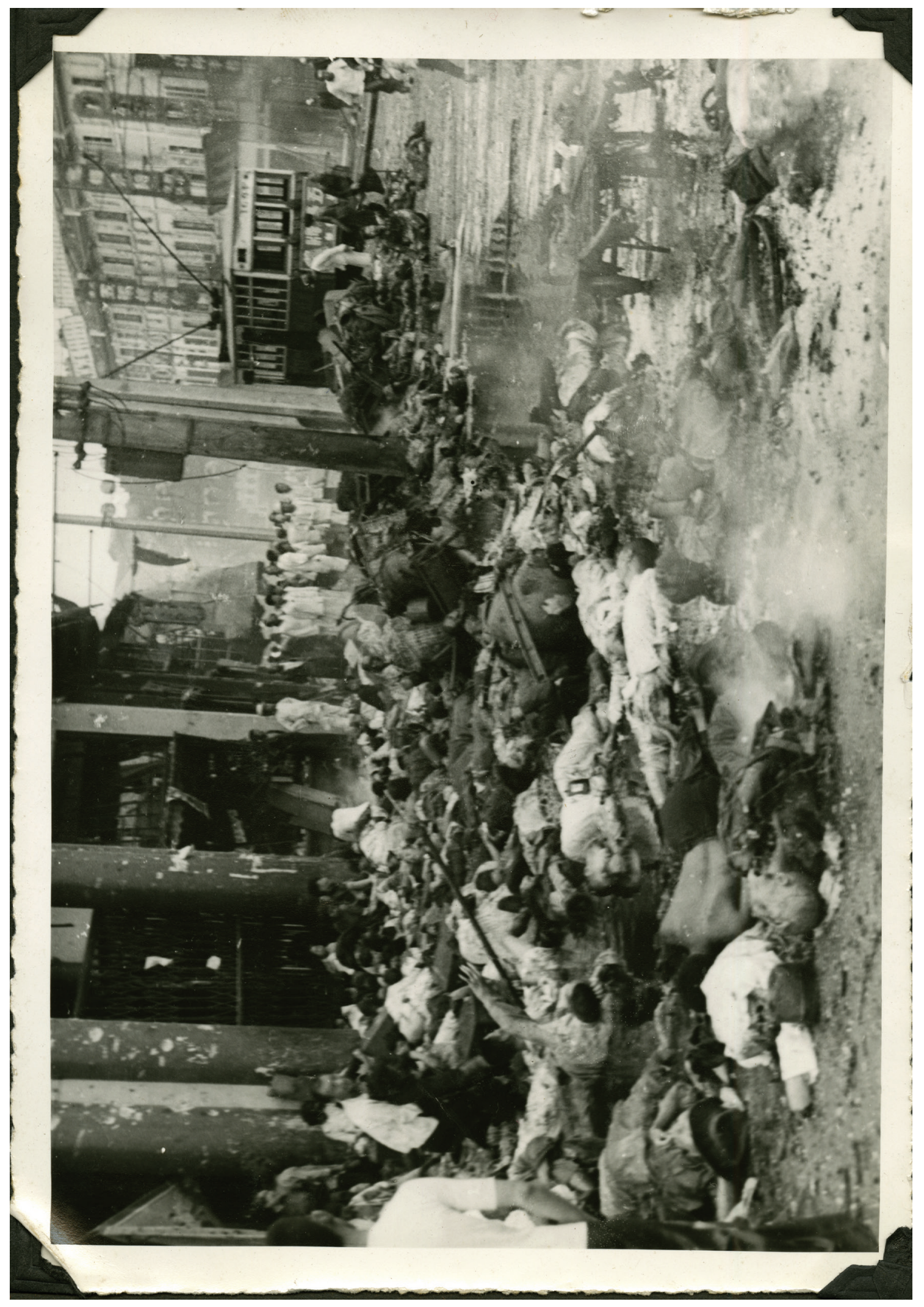

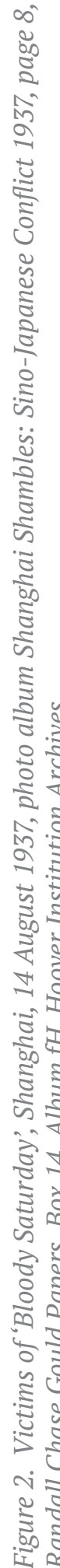




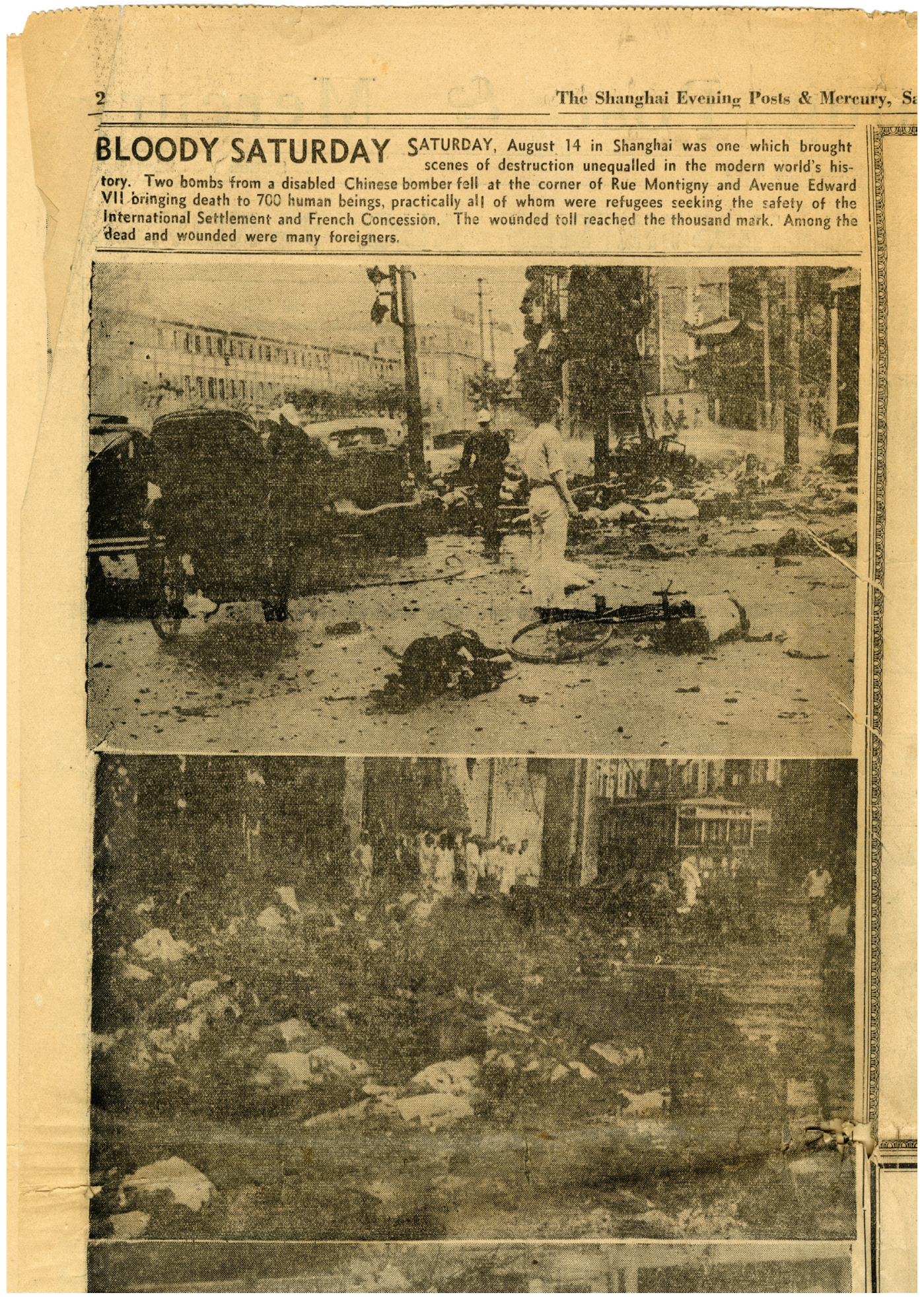

Figure 3. Photographs illustrating 'Bloody Saturday', published in the Pictorial Review of Shanghai Hostilities, Aug. 9 - Nov. 12, page 2, Shanghai Evening Post and Mercury, 4 December 1937, Randall Chase Gould Papers, Box 14, Hoover Institution Archives. 

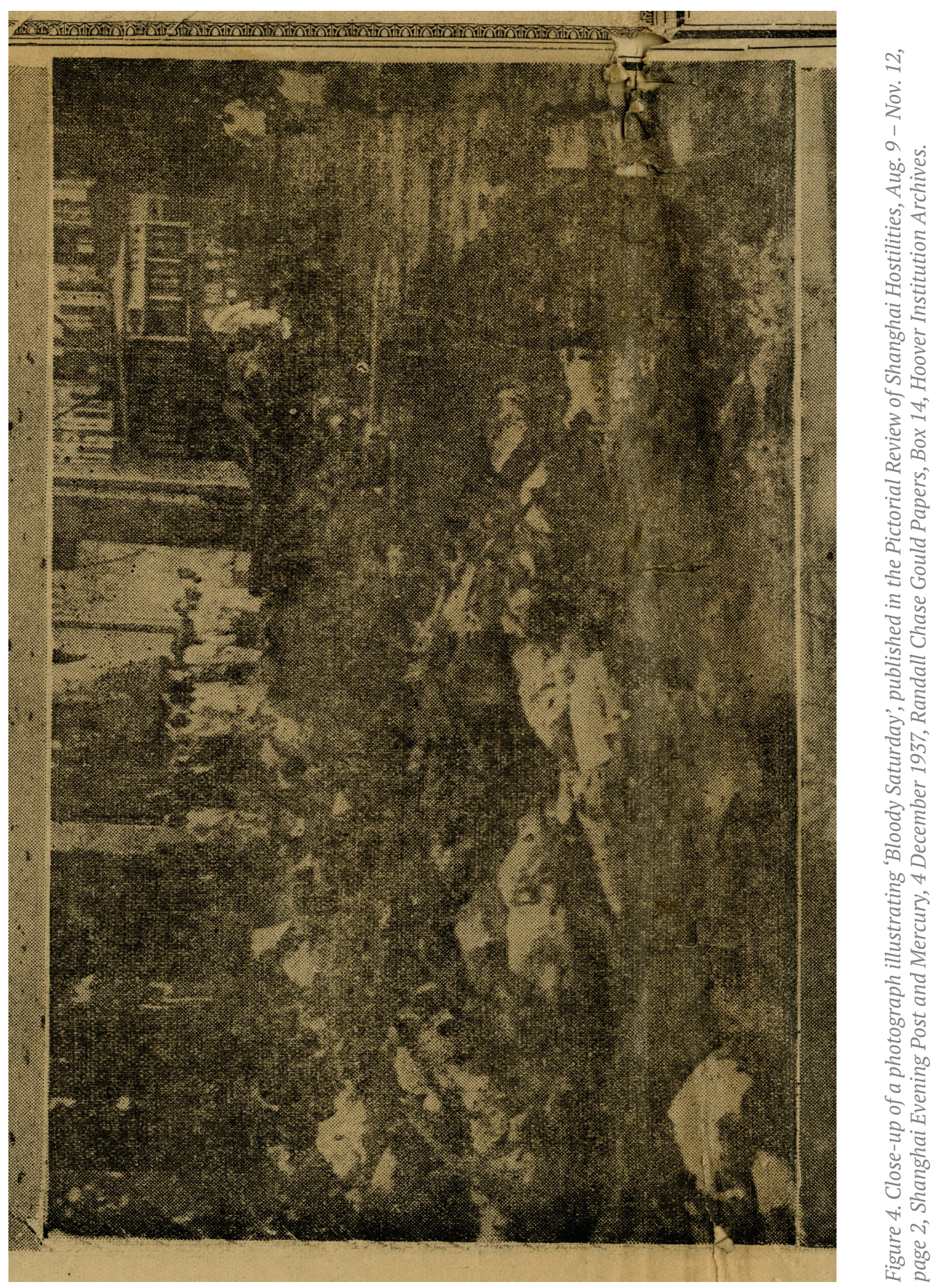
All of these alterations resulted in a change of the photograph's visual structure: in the newspaper version of the image, the focal point was placed more clearly on the numerous dead bodies, thus dramatising the image. This impression was further emphasised by cutting out uninjured people actively engaged in helping the victims in the image, thus leading the viewers to assume that there was little or no help available in this time of crisis, adding to the image's shock value. Through the act of cropping, the published version generally appears to have fewer empty spaces than the album version of the photograph, giving it a more compact, almost claustrophobic feeling. This effect not only concentrates the image's focal point on the dead bodies, but subtly suggests that there might be even more victims just out of frame. Cropping photographs to guide the viewers' gaze was one of the principal techniques in photojournalism at the time. The goal of cropping, along with the use of contrasting backgrounds and the publishing of large-scale images, was to emphasise what was important in the eyes of editors and publishers. ${ }^{54}$ The act of cropping the 'Bloody Saturday' photograph thus shows how the image's visual structure was changed to maximise its ability to direct and hold the gaze of the highest number of readers through dramatisation and shock value.

Both versions of the photograph were accompanied by text or a short caption. In his 1970 Key to Photo Album Shanghai Shambles, Gould provided background information regarding the bombing, including the date, location and number of victims: 'Start of pictures of the second accidental bombing of Shanghai Aug. 14., this being the one which killed about 1,600 refugees in the big 'Great World' intersection of Avenue Edward VII and Tibet Road. ${ }^{55}$ Aside from this basic information, the captions also contained further details: 'The force of the blast caused bodies to be heaped in piles for some distance off the intersection. For many days bodies were left in the open away from traffic. Few were ever identified. ${ }^{56}$ In short, matter-of-fact sentences, Gould explained why the bodies appeared arranged in piles in the photographs. The printed image published in the Pictorial Review was also accompanied by text. The caption, located at the top and intended for all images on the page, reads:

Bloody Saturday: Saturday, August 14 in Shanghai was one which brought scenes of destruction unequalled in the modern world's history. Two bombs from a disabled Chinese bomber fell at the corner of Rue Montigny and Avenue Edward VII bringing death to 700 human beings, practically all of whom were refugees seeking the safety of the International Settlement and French Concession. The wounded toll reached the thousand mark. Among the dead and wounded were many foreigners. ${ }^{57}$ 
Apart from providing information on the bombing, the caption clearly emphasised the fact that this level of death and destruction was unprecedented in Shanghai. The text thus employed a stylistic device aimed at accomplishing three tasks: capture the readers' attention, lead them to the main point of the caption focusing on the dead and wounded, and guide their gaze to the bodies in the images.

When comparing the captions printed in the Pictorial Review with the captions written by Gould in his key to the photo album, several differences can be observed. While both texts delivered information regarding what happened that day, the differences in tone are striking. Gould's captions from 1970 conveyed a sense of detachment based on their matter-of-fact tone, while the printed captions resonated with a sense of urgency and emphasis. Mirroring and maximising the effect of cropping the image from Gould's album showing the aftermath of the 'Bloody Saturday' bombing, the printed text invited the readers to focus on the most shocking part - the victims and their suffering - with the ultimate goal of catching the readers' eye and conveying a sense of horror.

In addition, the caption in the Pictorial Review specifically mentioned foreigners being killed in the bombing, while Gould's caption did not. Although the overwhelming majority of victims were Chinese, the printed caption directly addressed its transnational Shanghai audience by highlighting the existence of both Chinese and foreign victims. ${ }^{58}$ It invited readers to study the bodies in the photograph and to reflect on the impact and the horrors of the mass killing, which had affected not only refugees but also the seemingly protected foreign communities, shattering their sense of security and safety.

These mechanisms underline that the captions not only delivered basic information, but also reflected and enhanced the visual strategies of the photograph through text, thus echoing the Barthesian concept of the visual and linguistic structures creating the photographic message together. Moreover, the act of cropping the image further augmented the message of the visual structure by enhancing its sense of shock and urgency. In doing so, the Pictorial Review not only acknowledged but actively used the power of the image to capture the attention of Shanghai's transnational audiences, with the goal of imparting its message to the widest possible readership without even requiring them to read the caption. Therefore, the image took on an essential position in the context of transnational news reporting. 


\section{Conclusion: Press photographs and their strategies in transnational contexts}

This study has closely examined two photographs taken by Randall Chase Gould on 14 August 1937: one of them depicting refugees streaming across the Garden Bridge and the other showing the aftermath of bombing on the day that would become known as 'Bloody Saturday'. The close reading of the 'Garden Bridge' photograph in three transnational contexts has revealed how the dynamic interrelation between linguistic and visual structures led to three diverging photographic messages destined for varying target audiences. In emphasising specific aspects in the photograph, the captions directed the viewers' gaze, leading them to observe the image in a particular way.

The unique possibility to analyse both the album version and the published version of the 'Bloody Saturday' photograph has revealed a rare insight into the techniques and effects of image editing used in the early stages of photojournalism in the 1930s. By cropping any signs of aid being offered, the published image was dramatised and had a sole focal point: the deaths and suffering of Shanghai's civilians. Together with its caption, the photograph represented an example of how linguistic and visual techniques were used together as strategies to capture and guide a transnational audience's attention. On the one hand, the caption directly addressed Shanghai's English-speaking residents by specifying that both Chinese refugees and foreigners had perished as a result of the bombing. On the other hand, the image was directed at everyone, thus joining all audiences of Shanghai in their collective shock by delivering the news without the presumption of every person reading and understanding its caption. Edited to be centred on the hopelessness of the situation, the photograph delivered the message beyond linguistic or cultural constraints, underlining its critical and decisive role in transnational contexts.

These two case studies have shown that photographs were not used to 'simply' illustrate the news. Instead, they served as a major tool for newspaper publishers to communicate a single or several messages to their audiences - either in conjunction with or even without relying on their accompanying texts. In doing so, the images directly involved their respective viewership by connecting to each reader's frame of reference, regardless of whether they were outsiders or insiders in terms of their war experiences. At first glance, Gould's images seemed to simply provide a report on the beginning of the Second Sino-Japanese War as seen by an American editor. However, by systematically analysing both the visual and textual structures in several transnational publication contexts, this contribution has shown how Gould's photography was used strategically to encourage 
certain readings of news items. This study has underlined photography's status and significance as an integral and self-contained part of news appearing in transnational and multilingual contexts. While the case studies presented here have shed some light on these issues, more research remains to be conducted regarding the reception of photography in transnational media, as well as the wider embedding of photojournalism in transnational journalism history.

\section{Notes}

1. This article is based on research financed by the Swiss National Science Foundation (SNSF) through Doc. CH grant no. 175406. It is part of the larger framework of the author's ongoing dissertation project, conducted at the University of Zurich, Switzerland, titled "Through the Multifocal Lens: Visual Representation in Newspaper Photography on China, 1925-1949”. An earlier version of this article has been presented at the $4^{\text {th }}$ Transnational Journalism History Conference at the Centre for Media and Journalism Studies of the University of Groningen (the Netherlands), 20-21 June 2019.

2. The designation 'Second Sino-Japanese War' is widely used in Western contexts, but in China, the war is generally identified as the 'War of Resistance against Japanese Aggression' (抗日戰爭 Kangri Zhanzheng).

3. Christian Henriot, "Shanghai and the Experience of War: The Fate of Refugees," European Journal of East Asian Studies 5, 2 (2006): 215-245, 215-217, DOI: 10.1163/157006106778869306.

4. Isabella Jackson, Shaping Modern Shanghai: Colonialism in China's Global City (Cambridge: Cambridge University Press, 2018), 17.

5. Ibid., $4,17$.

6. Ibid., 7.

7. Marie Cronqvist and Christoph Hilgert, "Entangled Media Histories: The Value of Transnational and Transmedial Approaches in Media Historiography,” Media History 23, 1 (2017): 130-141, 132, DOI: 10.1080/13688804.2016.1270745.

8. Marlen E. Pew, Jr., “China War Costs Services More Than Any Event Since 1917,” Editor \& Publisher, 4 September 1937, 5-6.

9. Shanghai Shambles: Sino-Japanese Conflict 1937, Randall Chase Gould papers, Boxes 14 and 15, Album fH, Hoover Institution Archives.

10. “Pictorial Review of Shanghai Hostilities, Aug. 9 - Nov. 12," Shanghai Evening Post and Mercury, 4 December 1937, 1-24. Randall Chase Gould papers, Box 14, Hoover Institution Archives. 
11. Roland Barthes, Image Music Text, trans. Stephen Heath (London: Fontana Press, 1977), 16.

12. Marcel Broersma, "Transnational Journalism History: Balancing Global Universals and National Peculiarities," Medien \& Zeit 4 (2010): 10-15, 12, https://medienundzeit.at/wp-content/uploads/2015/04/ MZ_2010-04.pdf, accessed 10 May 2020.

13. Susan Sontag, Regarding the Pain of Others (New York: Farrar, Straus and Giroux, 2003), 20.

14. Barthes, Image Music Text, 16.

15. Consulat General de France à Shanghai, “Etude sur la Presse à Changhai,” ca. 1930, 635PO/A/153, 1-15, 2. Centre des Archives diplomatiques de Nantes.

16. Yong Z. Volz and Chin-Chuan Lee, "Semi-Colonialism and Journalistic Sphere of Influence," Journalism Studies 12, 5 (November, 2011): 559-574, 562, DOI: 10.1080/1461670X.2010.527551.

17. Ibid., 562.

18. George C. Bruce, letter to the French Consul General, 15 June 1938. 635/PO/150, Centre des Archives diplomatiques de Nantes.

19. Randall Chase Gould, Three p.m. Shanghai Time: A Memoir in Three Parts, unpublished manuscript, undated, 122. Randall Chase Gould papers, Box 10, Hoover Institution Archives.

20. Peter O’Connor, The English-Language Press Networks of East Asia, 1918-1945 (Folkestone: Global Oriental, 2010), 142.

21. Ibid., 142; Yi Wang, “Journalism under Fire in China: The Shanghai Evening Post and Mercury 1929-1949” (PhD diss., University of Tasmania, 2016), 77, https://eprints.utas.edu.au/23478/1/Wang_whole_thesis.pdf, accessed 16 May 2020.

22. Gould, Three p.m. Shanghai Time, 121. Randall Chase Gould papers, Box 10, Hoover Institution Archives; Carl Crow, Inc., ed., Newspaper Directory of China \& Advertising Manual 1937 (Shanghai: Carl Crow, Inc., 1937), 131.

23. Report on the circulation of foreign newspapers in Shanghai, 31 January 1940, 1-3, 1.635PO/A/152, Centre des Archives diplomatiques de Nantes.

24. Shuge Wei, News under Fire: China's Propaganda against Japan in the English-Language Press, 1928-1941 (Hong Kong: Hong Kong University Press, 2017), 109.

25. Gould, Three p.m. Shanghai Time, 129. Randall Chase Gould papers, Box 10, Hoover Institution Archives.

26. Translation by author. Consulat General de France à Shanghai, “Étude sur la Presse à Changhai,” ca. 1930, 635PO/A/153, 1-15, 12. Centre des Archives diplomatiques de Nantes. 
Original quote: 'Bien que le "Shanghai Evening Post \& Mercury” professe une grande impartialité à l'égard des aspirations nationalistes chinoises, la présence de M. W. Woodhead, l'un des “die-hards” britanniques les plus notoires, au sein de sa rédaction, font du journal un des défenseurs les plus actifs des droits des étrangers en Chine.'

27. Gould, Three p.m. Shanghai Time, 121-122. Randall Chase Gould papers, Box 10, Hoover Institution Archives.

28. Ibid., 121

29. Ibid., 153.

30. O’Connor, The English-Language Press Networks of East Asia, 143.

31. Ibid., 142 .

32. Ibid., 98.

33. Gould, Three p.m. Shanghai Time, 192. Randall Chase Gould papers, Box 10, Hoover Institution Archives.

34. These tensions can be traced back to the nineteenth century, when China and Japan engaged in a power struggle with the goal of gaining and maintaining control over Korea, which led to the outbreak of the First Sino-Japanese War (1894-1895) and ended with Japanese victory. Japan’s expansionist policies in China continued to intensify, which were reflected in the Japanese occupation of Manchuria after the so-called 'Manchurian Incident' on 18 September 1931, and the subsequent establishment of the Japanese puppet state Manchukuo in 1932. See Louise Young, Japan's Total Empire: Manchuria and the Culture of Wartime Imperialism (Berkeley: University of California Press, 1998), 24.

35. Henriot, "Shanghai and the Experience of War," 216-219.

36. In December 1941, on the day of the Attack on Pearl Harbor, the Japanese moved into the International Settlement, thus occupying the whole city, sparing only the French Concession, which was then under the rule of a Vichy government-appointed consul. See Wen-hsin Yeh, "Prologue: Shanghai Besieged, 19371945," in Wartime Shanghai, ed. Wen-hsin Yeh (London: Routledge, 1998), 1-16, 2.

37. Henriot, "Shanghai and the Experience of War," 218.

38. For example, both Rana Mitter and Paul French refer to Gould's photographs. See Rana Mitter, China's War with Japan, 1937-1945 (London: Allen Lane, 2013), 93, and Paul French, Through the Looking Glass: China's Foreign Journalists from Opium Wars to Mao (Hong Kong: Hong Kong University Press, 2009), 196.

39. The photograph is titled "Battle of Pootung Point" and depicts a burning ship in the harbour. See "The Hostilities In and Around Shanghai," North-China Herald and Supreme Court \& Consular Gazette, 1 December 1937, 358. 
40. Gould, Three p.m. Shanghai Time, 276. Randall Chase Gould papers, Box 10, Hoover Institution Archives.

41. “The Movie Camera as a War Weapon," Popular Photography, April 1944, 66-68, 66.

42. Albums fB, fC, fD, fE, fF, fH, Randall Chase Gould papers, Hoover Institution Archives.

43. Shanghai Shambles: Sino-Japanese Conflict 1937, Randall Chase Gould papers, Boxes 14 and 15, Album fH, Hoover Institution Archives

44. Randall Chase Gould, Key to Photo Album Shanghai Shambles, 1970, 1-8. Randall Chase Gould papers, Box 14, Hoover Institution Archives.

45. Ibid., 1.

46. “The Chinese Outfight the Japanese as Shanghai Blazes," Life Magazine, 13 September 1937, 23-26, 24.

47. Ibid., 25.

48. 英文大美晚報出版 (yingwen da mei wan bao chu ban) English-language Shanghai Evening Post and Mercury, ed., 中日戰事史蹟 zhongri zhanshi shiji [A Historical Account of the Sino-Japanese Hostilities], 1938.

49. Ibid., 11.

50. Randall Gould, “Covering the War,” Leica Photography 6, 3 (December, 1937), 4, 9.

51. Ibid., 4.

52. Ibid., 4.

53. While the exact number of victims remains elusive, the two bombings on 14 August 1937 killed at least 1,200 people and wounded hundreds more. The very beginning of the war in Shanghai thus claimed the highest number of civilian victims. See: Christian Henriot, "August 1937: War and Death en masse of Civilians,” in War and History in Memory, ed. Lü Fangshang (Taipei: Academia Historica, 2015), 60-126, 60.

54. William S. Howland, "Pictorial Journalism Strives Forward,” The Quill, January - February 1944, 18.

55. Gould, Key to Photo Album Shanghai Shambles, 1, Randall Chase Gould papers, Box 14, Hoover Institution Archives.

56. Ibid.

57. “Pictorial Review of Shanghai Hostilities, Aug. 9 - Nov. 12," Shanghai Evening Post and Mercury, 4 December 1937, 2. Randall Chase Gould papers, Box 14, Hoover Institution Archives.

58. Most victims were Chinese, and the number of foreign victims who perished during the 'Great World' bombing remained in single digits. See Henriot, “August 1937,” 87. 


\section{Biography}

Anna Elisabeth Herren obtained her M.A. degree in East Asian Art History and Chinese studies at the University of Zurich, Switzerland, in 2016. She is a recipient of a Doc.CH grant awarded to her in 2017 by the Swiss National Science Foundation and she is currently conducting her PhD project at the Institute of Art History, Section for East Asian Art History at the University of Zurich. Her research focus is on visual representation in newspaper photography reporting on China from 1925 to 1949 , and her research interests include photography, photojournalism and journalism in and concerning China during the Republican Era.

TMG Journal for Media History

Volume 24 No $(1 / 2) / 2021$

DOI

http://dx.doi.org/10.18146/tmg.782

PUBLISHER

Netherlands Institute for Sound and Vision

\section{COPYRIGHT}

Each article is copyrighted (c) by its author(s) and is published under license from the author(s). When a paper is accepted for publication, authors will be requested to agree with the Creative Commons Attribution 4.0 International License. 